\title{
The effect of electrolyte constituents on contact glow discharge electrolysis
}

\author{
Xinglong Jin ${ }^{\mathrm{a}, *}$, Xiaoyan Wang ${ }^{\mathrm{a}}$, Junjie Yue ${ }^{\mathrm{a}}$, Yaqi Cai ${ }^{\mathrm{b}}$, Hongyu Zhang ${ }^{\mathrm{a}}$ \\ a School of Environmental Science and Safety Engineering, Tianjin University of Technology, Tianjin 300384, China \\ b State Key Laboratory of Environmental Chemistry and Ecotoxicology, Research Center for Eco-Environmental Sciences, Chinese Academy of Sciences, Beijing 100085, China
}

\section{A R T I C L E I N F O}

\section{Article history:}

Received 6 August 2010

Received in revised form

20 September 2010

Accepted 26 September 2010

Available online 25 October 2010

\section{Keywords:}

Contact glow discharge electrolysis

Electrolyte

Conductivity

Critical voltage

Hydrogen peroxide

\begin{abstract}
A B S T R A C T
Ordinary electrolysis developed spontaneously to contact glow discharge electrolysis (CGDE) at sufficiently high voltage, with glow discharge taking place around a thin platinum anode which was in contact with electrolyte solution. During this transition, the critical voltage $\left(V_{\mathrm{D}}\right)$ was an important parameter for the onset of CGDE. The results indicated that $V_{D}$ decreased with the increasing conductivity and then maintained a certain value. The different dimension and material of cathode had little effect on $V_{D}$. When the electrolyte conductivity was $5.0 \mathrm{mS} / \mathrm{cm}, V_{\mathrm{D}}$ was hardly affected by electrolyte composition. And the concentrations of $\mathrm{H}_{2} \mathrm{O}_{2}$ producing in the anolyte were close in different inert electrolyte. However, the concentrations of $\mathrm{H}_{2} \mathrm{O}_{2}$ in $\mathrm{NaCl}, \mathrm{NaAc}, \mathrm{Na}_{2} \mathrm{CO}_{3}$ and $\mathrm{NaHCO}_{3}$ solution were lower than that in $\mathrm{Na}_{2} \mathrm{SO}_{4}$ solution. And the concentration of $\mathrm{H}_{2} \mathrm{O}_{2}$ in the anolyte was also decreased by adding a minute amount of $\mathrm{CH}_{3} \mathrm{OH}$.
\end{abstract}

(C) 2010 Elsevier Ltd. All rights reserved.

\section{Introduction}

Nowadays, electrochemical discharge has been used in a variety of fields such as hydrogen production, micro-machining, nanoparticle synthesis, wastewater treatment and so on [1]. It was also termed in literature as plasma electrolysis [2], electrode effects [3-6] (anode or cathode effects depending on which electrode the phenomena takes place) or contact glow discharge electrolysis (CGDE) [7-9]. The understanding of electrochemical discharge continued with the increasing interest for its application. Kellogg focused on the anode effect in aqueous electrolyte and discovered the characteristic transition region, then named kellogg's region [10]. Hickling and Ingram investigated the factors governing the breakdown of conventional electrolysis and found the chemical effect of CGDE was closely similar to resemble the alpha radiolysis of water [11]. Vogt investigated the parameters of influencing the onset of electrode effect and presented mathematical models for the incremental ohmic resistance [12], the formation of gas film and bubble coverage fraction $[3,6]$. They found that deteriorated wetting of the electrode-electrolyte interface and decreasing rate of bubble release were two other important effects of electrochemical discharge, besides local evaporation of the electrolyte by Joule heating [1].

In recent years, much attention has been paid to CGDE for its production of $\bullet \mathrm{OH}$. In CGDE, plasma was sustained by direct cur-

\footnotetext{
* Corresponding author. Tel.: +8622 60214185; fax: +862260214185.

E-mail address: xljin7911@126.com (X. Jin).
}

rent glow discharge between the electrode and the electrolyte surface [7-9]. Using a thin platinum anode in contact with an electrolyte solution, the conventional electrolysis could develop spontaneously to CGDE when the applied voltage was sufficiently high [13]. During the transition process, $I-V$ (current vs voltage) curve was characteristic to CGDE. Sengupta and Singh studied the onset, location and chemical effect of CGDE in H-type reactor [7]. They found that $V_{\mathrm{D}}$ depended on the polarity of the electrode ( $420 \mathrm{~V}$ for the anode and $160 \mathrm{~V}$ for the cathode in aqueous solution) and was unaffected by the electrolyte composition, concentration, temperature and surface tension. However, our recent research indicated that $V_{\mathrm{D}}$ decreased with the increasing conductivity when the conductivity of electrolyte changed from 0.91 to $8.66 \mathrm{mS} \mathrm{cm}^{-1}$ [14]. It was necessary to proceed towards completely understanding the onset of CGDE. At the same time, it was well established that CGDE generate active radicals $\left(\bullet \mathrm{OH}, \mathrm{H}_{2} \mathrm{O}_{2}\right.$, etc.) which made it particularly suitable for decontamination purpose. Many papers have presented results on destruction efficiencies of phenols $[15,16]$, organic dyes and production efficiencies of hydrogen peroxide [17-19]. However, the effect of electrolyte composition has not been systematically studied so far. In this study, we did a series of experiments in order to further address these problems.

\section{Experimental}

Experimental apparatus was similar to that in our previous work [14]. The anode was a platinum wire $(0.30 \mathrm{~mm})$ held in the brass support sealed into a glass tube. The cathode was a graphite stick (diameter: $3.92 \mathrm{~mm}$ ) placed in another glass tube, which was cov- 
ered at the bottom by a sinter glass disk of medium porosity. Electrolyte solutions with certain conductivity were prepared by dissolving electrolyte in the distilled water. Dissolved oxygen was removed from the electrolyte. The platinum wire was immersed into the solution to a depth of approximately $1.0 \mathrm{~mm}$. In addition, the reaction cell was placed in a temperature-controlled water bath and the temperature of electrolyte was remained at $30^{\circ} \mathrm{C}$. The solution was gently stirred with a magnet bar during the reaction. The voltage was applied through a direct current power supply (variable voltage $0-1000 \mathrm{~V}$ and current $0-300 \mathrm{~mA}$ ).

To reduce the amount of sampling and improve the reliability of results by replicate determination of multiple samples, spectrophotometry was carried on microplates by Multiskan Spectrum (Thermo Scientific, America) after confirming a Cary 50 UV-vis spectrometer (Varian, America). It was used to determine the concentration of $\mathrm{H}_{2} \mathrm{O}_{2}$ producing in the process of CGDE. The determination of $\mathrm{H}_{2} \mathrm{O}_{2}$ was based on the reaction of $\mathrm{H}_{2} \mathrm{O}_{2}$ with titanyl ions giving yellow-colored complex of pertitanic acid [20]:

$\mathrm{Ti}^{4+}+\mathrm{H}_{2} \mathrm{O}_{2}+2 \mathrm{H}_{2} \mathrm{O} \rightarrow \mathrm{TiO}_{2} \cdot \mathrm{H}_{2} \mathrm{O}_{2}+4 \mathrm{H}^{+}$

\section{Results and discussion}

\subsection{I-V characteristic}

A series of experiment was conducted in different electrolyte solution to investigate the characteristic of anodic CGDE. Fig. 1 illustrated the typical $I-V$ curve in $\mathrm{Na}_{2} \mathrm{SO}_{4}$ solution. In the mean stationary $I-V$ characteristics, several different regions were identified:

$0<V<V_{\mathrm{A}}$ : ohmic region; electrolysis of water took place and conventional electrolysis occurred with small bubbles of gas leaving the anode.

$V_{\mathrm{A}}<V<V_{\mathrm{B}}$ : limiting current region (or region of current saturation); bubbles were coalescing to the anode and the bubble coverage fraction increased. $V_{\mathrm{B}}$ was termed as the breakdown voltage in reference.

$V_{\mathrm{B}}<V<V_{\mathrm{D}}$ : transition region; $V_{\mathrm{D}}$ was the critical voltage (also termed as midpoint voltage in reference). The transition region was also divided into three parts as follows.

$V_{\mathrm{B}}<V<V_{\mathrm{C}}$ : a sharp decrease was observed. A vapor sheath appeared and progressively covered the anode surface. The bub-

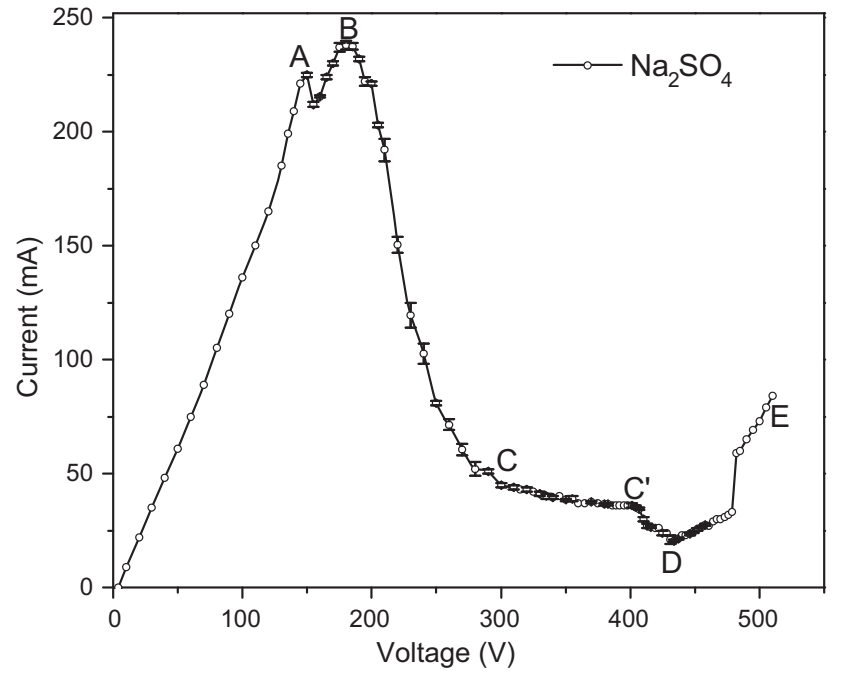

Fig. 1. $I-V$ curve of CGDE in $\mathrm{Na}_{2} \mathrm{SO}_{4}$ solution (conductivity: $8.20 \mathrm{mS} / \mathrm{cm}$ ).

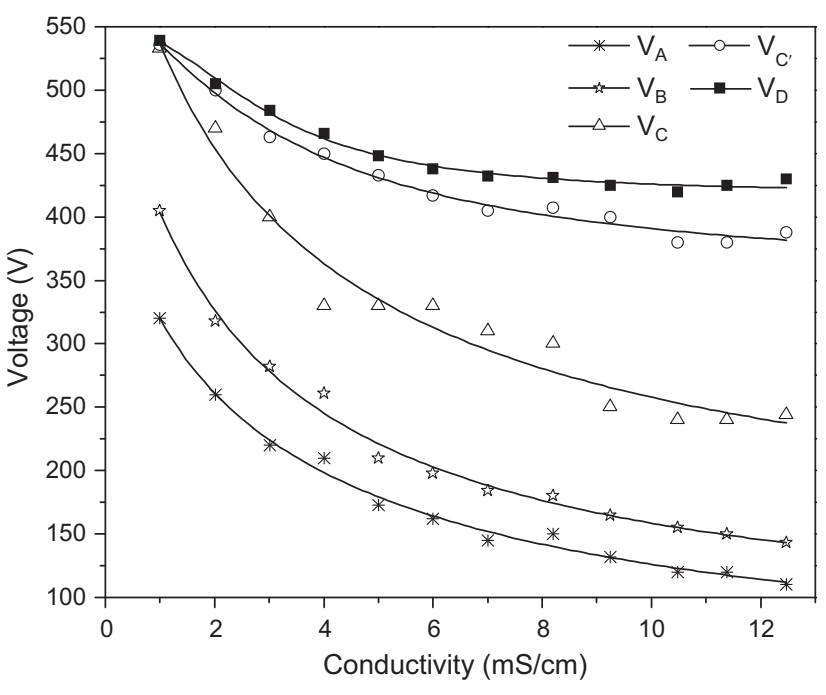

Fig. 2. Variation of characteristic voltage with the conductivity of $\mathrm{Na}_{2} \mathrm{SO}_{4}$ solution.

bles in vapor sheath underwent the process of formation and collapse, the oscillation of the current occurred.

$V_{\mathrm{C}}<V<V_{\mathrm{C}^{\prime}}$ : the stabilized vapor sheath appeared around the anode. The current became stable.

$V_{\mathrm{C}^{\prime}}<V<V_{\mathrm{D}}$ : the compact vapor sheath built up around the anode and progressively covered the anode surface.

$V>V_{\mathrm{D}}$ : glow discharge electrolysis region; the vapor sheath covered all active bubble nucleation sites of the anode; current transport happened through glow discharge. The current started to increase steadily with the rising voltage and violet glow appeared in the anode. In section DE, glow discharge became yellow.

Since CGDE was still an electrochemical process and the glow discharge was transferred by ions, it was evident that the conductivity of the solution had an influence on the onset of CGDE. In this study, CGDE were conducted in $\mathrm{Na}_{2} \mathrm{SO}_{4}$ solution with its conductivity changing from 1.00 to $12.47 \mathrm{mS} / \mathrm{cm}$, and in $\mathrm{Na}_{2} \mathrm{HPO}_{4}$ solution with its conductivity in the range of $2.01-12.00 \mathrm{mS} / \mathrm{cm}$. The results were shown in Fig. 2 and Fig. 3, respectively. It was found that the characteristic value of $V_{\mathrm{A}}, V_{\mathrm{B}}, V_{\mathrm{C}}$ and $V_{\mathrm{C}^{\prime}}$ decreased with increasing conductivity in $\mathrm{Na}_{2} \mathrm{SO}_{4}$ solution and $\mathrm{Na}_{2} \mathrm{HPO}_{4}$ solution. However, $V_{\mathrm{D}}$ decreased with the increase of conductivity, and then maintained a certain value. This result demonstrated that the

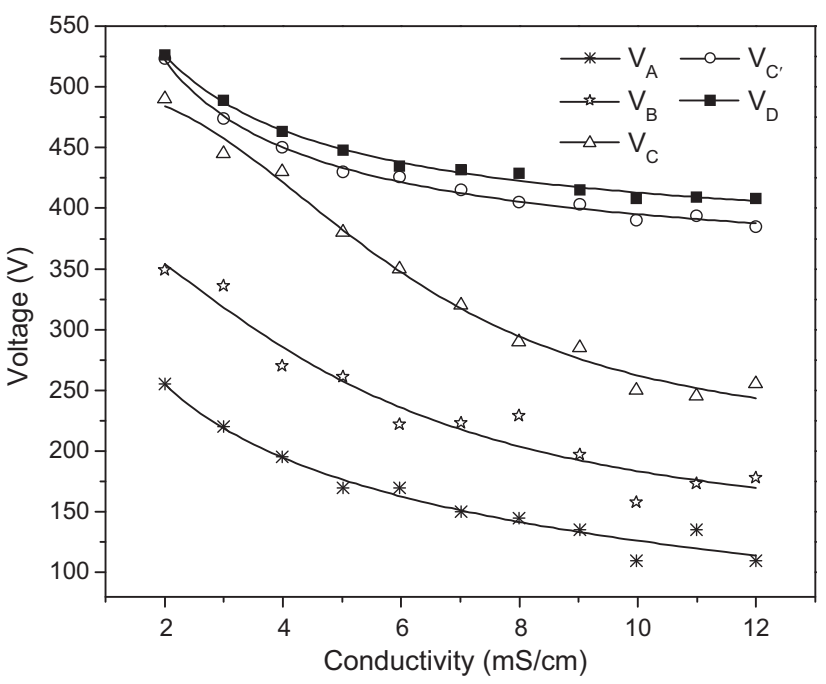

Fig. 3. Variation of characteristic voltage with the conductivity of $\mathrm{Na}_{2} \mathrm{HPO}_{4}$ solution 
conductivity was one of important factors influencing the onset of CGDE. The increment of conductivity resulted in a higher current density at the same applied voltage and the power dissipation in the vicinity of the anode became relatively higher. The vapor sheath and the glow discharge were easy to generate. Another critical factor for the onset of CGDE was a sufficient potential drop to cause an appreciable conduction through the gas phase. The critical voltage should be sufficiently high to sustain the potential drop through glow discharge. Therefore, the onset of CGDE was correlated with both the voltage and the conductivity of the solution.

\subsection{Effect of conductivity on $V_{D}$}

Since $V_{\mathrm{D}}$ was the critical voltage for the onset of CGDE, much attention had been paid on the parameters influencing on it. It had been found in the previous work that $V_{\mathrm{D}}$ decreased with the increase of conductivity in the range of $0.91-8.66 \mathrm{mS} / \mathrm{cm}$ [14]. In this study, $V_{\mathrm{D}}$ in $\mathrm{Na}_{2} \mathrm{SO}_{4}$ solution was investigated in the range of $1.00-11.38 \mathrm{mS} / \mathrm{cm}$ as shown in Fig. 4 . When the conductivity of $\mathrm{Na}_{2} \mathrm{SO}_{4}$ solution changed from $1.00 \mathrm{mS} / \mathrm{cm}$ to $5.99 \mathrm{mS} / \mathrm{cm}, V_{\mathrm{D}}$ decreased from $542 \mathrm{~V}$ to $438 \mathrm{~V}$. When the conductivity of $\mathrm{Na}_{2} \mathrm{SO}_{4}$ solution was $7.00,8.20,9.25,10.48$ and $11.38 \mathrm{mS} / \mathrm{cm}$, the values of $V_{D}$ were $432,431,425,420$ and $425 \mathrm{~V}$, respectively [7]. The magnitudes of $V_{D}$ were close to $420 \mathrm{~V}$, obtained from Sengupta's experimental result. That is, when the conductivity of solution was in the range of $7.00-11.38 \mathrm{mS} / \mathrm{cm}$, the effect of conductivity on $V_{\mathrm{D}}$ was largely not significant.

In the case of $\mathrm{Na}_{2} \mathrm{HPO}_{4}$ solution, when the conductivity changed from 2.01 to $9.02 \mathrm{mS} / \mathrm{cm}, V_{\mathrm{D}}$ decreased from $526 \mathrm{~V}$ to $415 \mathrm{~V}$. When the conductivity of $\mathrm{Na}_{2} \mathrm{HPO}_{4}$ solution was $9.97,10.99$ and $12.00 \mathrm{mS} / \mathrm{cm}$, the values of $V_{\mathrm{D}}$ were 408,409 and 408 , respectively. $V_{\mathrm{D}}$ in both electrolyte solutions decreased with increasing their conductivity, and then maintained a certain value. In addition, in the range of $4.00-8.00 \mathrm{mS} / \mathrm{cm}, V_{\mathrm{D}}$ in $\mathrm{Na}_{2} \mathrm{SO}_{4}$ solution and $\mathrm{Na}_{2} \mathrm{HPO}_{4}$ solution were so close that two curves were overlapped which was shown in Fig. 4 . The difference of $V_{D}$ existed in the lower conductivity $(<4.00 \mathrm{mS} / \mathrm{cm})$ and in the higher conductivity (8.00-12.00 mS/cm).

In addition, the magnitudes of $V_{\mathrm{D}}$ were compared with those in the previous study, as shown in Fig. 5. In the range of $2.00-9.00 \mathrm{mS} / \mathrm{cm}$, the magnitudes of $V_{\mathrm{D}}$ were close. The diameters of stainless steel cathode (in the previous study) and graphite cathode were 2 and $3.92 \mathrm{~mm}$, respectively. That is to say, the effect of electrode dimension and cathode material on $V_{\mathrm{D}}$ was so little in this

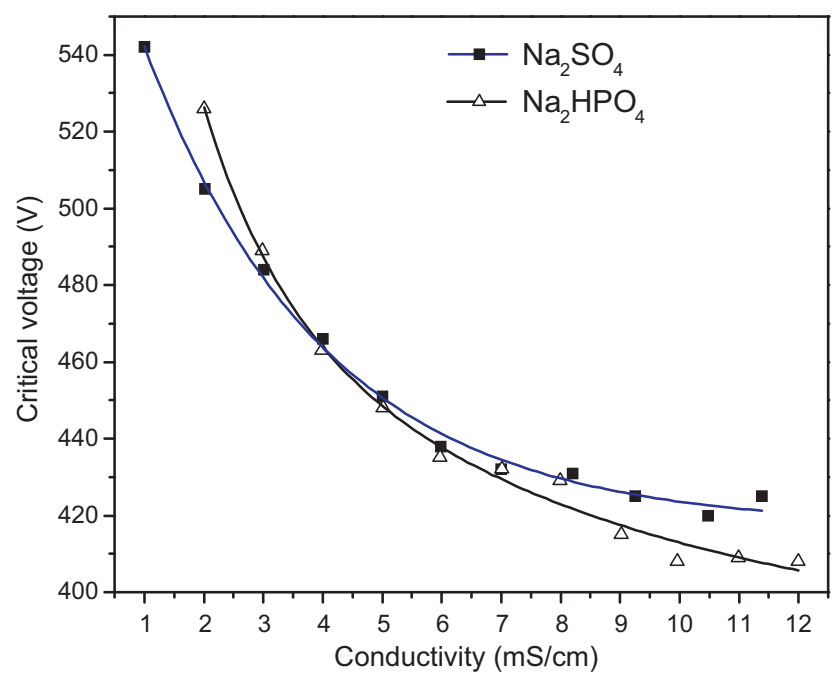

Fig. 4. Variation of $V_{D}$ with the conductivity of electrolyte.

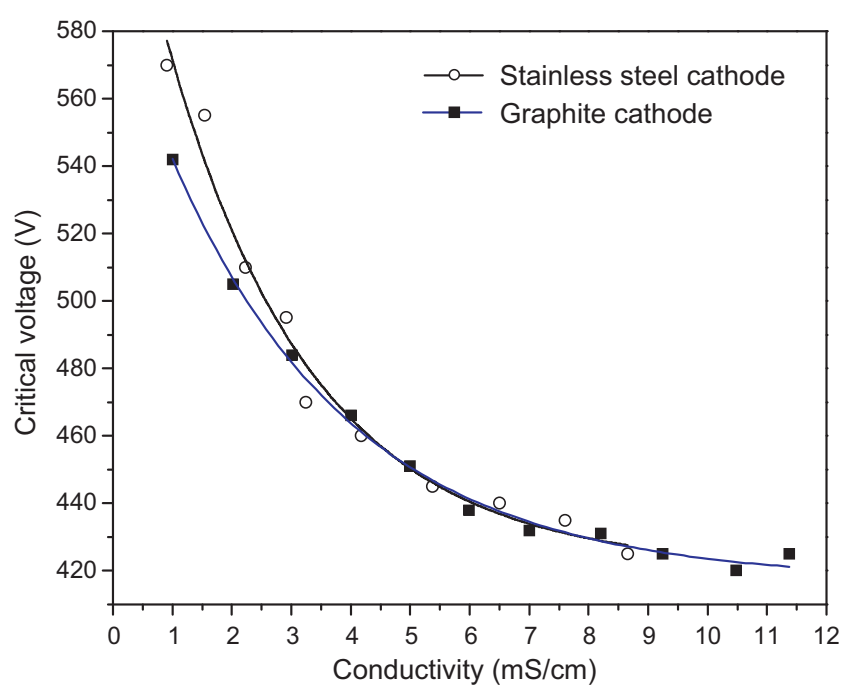

Fig. 5. The effect of cathode dimension and material on $V_{\mathrm{D}}$ in $\mathrm{Na}_{2} \mathrm{SO}_{4}$ solution.

range, which was consistent with Sengupta's experimental results [7].

At the same time, CGDE was also conducted in different electrolyte with the same conductivity, as shown in Table 1 . When the conductivity of solution was $5.00 \mathrm{mS} / \mathrm{cm}$, all values of $V_{\mathrm{D}}$ were very close in different electrolytes. Therefore, it could be concluded that $V_{\mathrm{D}}$ was unaffected by the electrolyte's composition if the conductivity of solution was given a specific value in a certain range. This result was consistent with the Sengupta's experimental results [7].

\subsection{Effect of electrolyte composition on chemical reactivity of plasma}

To characterize the chemical reactivity of plasma, the concentration of $\mathrm{H}_{2} \mathrm{O}_{2}$ was determined as a typical indicator of long living chemical compound. The effect of conductivity on the concentration of $\mathrm{H}_{2} \mathrm{O}_{2}$ has been investigated in our previous work [14]. The concentration of $\mathrm{H}_{2} \mathrm{O}_{2}$ increased with $\mathrm{CGDE}$ treatment time. The concentration of $\mathrm{H}_{2} \mathrm{O}_{2}$ producing in the anolyte increased with the increase of conductivity, and then maintained at a stationary value. In this study, we investigated the concentrations of $\mathrm{H}_{2} \mathrm{O}_{2}$ in different electrolytes with the same conductivity $5.00 \mathrm{mS} / \mathrm{cm}$. Table 1 listed the concentrations of $\mathrm{H}_{2} \mathrm{O}_{2}$ producing in different electrolytes after 20 min CGDE treatment. The concentrations of $\mathrm{H}_{2} \mathrm{O}_{2}$ accumulating in anolyte were $59.22 \mathrm{mg} / \mathrm{L}, 60.65 \mathrm{mg} / \mathrm{L}$ in $\mathrm{Na}_{2} \mathrm{SO}_{4}, \mathrm{Na}_{2} \mathrm{HPO}_{4}$ solution, respectively. The concentrations of

Table 1

The effect of electrolyte composition on CGDE under the same conductivity $(5.00 \mathrm{mS} / \mathrm{cm})$.

\begin{tabular}{lll}
\hline Electrolyte & $V_{\mathrm{D}}(\mathrm{V})$ & $\mathrm{C}_{\mathrm{H}_{2} \mathrm{O}_{2}}(\mathrm{mg} / \mathrm{L})$ \\
\hline $\mathrm{Na}_{2} \mathrm{SO}_{4}$ & 451 & 59.22 \\
$\mathrm{Na}_{2} \mathrm{HPO}_{4}$ & 451 & 60.65 \\
$\mathrm{Na}_{2} \mathrm{CO}_{3}$ & 456 & 47.87 \\
$\mathrm{NaHCO}_{3}$ & 450 & 43.35 \\
$\mathrm{NaCl}$ & 450 & 22.56 \\
$\mathrm{NaAc}$ & 452 & 41.26 \\
$\mathrm{Na}_{2} \mathrm{SO}_{4}+\mathrm{Na}_{2} \mathrm{HPO}_{4}$ & 450 & 63.26 \\
$\mathrm{Na}_{2} \mathrm{SO}_{4}+\mathrm{CuSO}_{4}$ & 452 & 64.01 \\
$\mathrm{Na}_{2} \mathrm{SO}_{4}+\mathrm{NaAc}$ & 453 & 64.66 \\
$\mathrm{Na}_{2} \mathrm{SO}_{4}+\mathrm{Na}_{2} \mathrm{CO}_{3}$ & 455 & 62.56 \\
$\mathrm{Na}_{2} \mathrm{SO}_{4}+\mathrm{NaHCO}_{3}$ & 459 & 59.60 \\
$\mathrm{Na}_{2} \mathrm{SO}_{4}+\mathrm{H}_{2} \mathrm{SO}_{4}$ & 458 & 63.85 \\
$\mathrm{Na}_{2} \mathrm{SO}_{4}+\mathrm{NaOH}$ & 458 & 64.02 \\
$\mathrm{Na}_{2} \mathrm{SO}_{4}+\mathrm{NaCl}$ & 452 & 56.58 \\
$\mathrm{Na}_{2} \mathrm{SO}_{4}+\mathrm{CH}$ & 46.71 \\
\hline
\end{tabular}


$\mathrm{H}_{2} \mathrm{O}_{2}$ in these two different electrolyte solutions were very close, since $\mathrm{Na}_{2} \mathrm{SO}_{4}$ and $\mathrm{Na}_{2} \mathrm{HPO}_{4}$ were inert electrolyte, which did not react with the active species of the plasma.

In $\mathrm{NaCl}$ solution, the concentration of $\mathrm{H}_{2} \mathrm{O}_{2}$ was $22.56 \mathrm{mg} / \mathrm{L}$ which was lower than that in $\mathrm{Na}_{2} \mathrm{SO}_{4}$ solution. It was because when the CGDE was performed in $\mathrm{NaCl}$ solution, $\mathrm{Cl}^{-}$could be transformed to chlorine radical. Two chlorine radicals reacted with each other to form molecular chlorine $\left(\mathrm{Cl}_{2}\right)$. $\mathrm{HClO}$ formed in reaction (4) then consumed $\mathrm{H}_{2} \mathrm{O}_{2}$ in anolyte [20]. Therefore, the concentration of $\mathrm{H}_{2} \mathrm{O}_{2}$ in $\mathrm{NaCl}$ solution was lower than that in $\mathrm{Na}_{2} \mathrm{SO}_{4}$ solution.

$\cdot \mathrm{OH}+\mathrm{Cl}^{-} \rightarrow \mathrm{Cl}^{\bullet}+\mathrm{OH}^{-}$

$\mathrm{Cl}^{\bullet}+\mathrm{Cl}^{\bullet} \rightarrow \mathrm{Cl}_{2}$

$\mathrm{Cl}_{2}+\mathrm{H}_{2} \mathrm{O} \rightarrow \mathrm{HCl}+\mathrm{HClO}$

$2 \mathrm{HClO}+\mathrm{H}_{2} \mathrm{O}_{2} \rightarrow 2 \mathrm{Cl}^{-}+{ }^{1} \mathrm{O}_{2}+2 \mathrm{H}^{+}$

In NaAc solution, the concentration of $\mathrm{H}_{2} \mathrm{O}_{2}$ was just $41.26 \mathrm{mg} / \mathrm{L}$ because $\mathrm{Ac}^{-}$consumed part of $\bullet \mathrm{OH}$ which resulted in the decrease of the concentration of $\mathrm{H}_{2} \mathrm{O}_{2} \cdot \mathrm{Na}_{2} \mathrm{CO}_{3}$ and $\mathrm{NaHCO}_{3}$ were often employed as inhibitor for ${ }^{\circ} \mathrm{OH}$. The rate constants between $\mathrm{Na}_{2} \mathrm{CO}_{3}$, $\mathrm{NaHCO}_{3}$ and $\cdot \mathrm{OH}$ were $8.9 \times 10^{8} \mathrm{M}^{-1} \mathrm{~s}^{-1}, 8.5 \times 10^{6} \mathrm{M}^{-1} \mathrm{~s}^{-1}$. The concentration of $\mathrm{H}_{2} \mathrm{O}_{2}$ in $\mathrm{Na}_{2} \mathrm{CO}_{3}$ and $\mathrm{NaHCO}_{3}$ solution were 47.87 and $43.35 \mathrm{mg} / \mathrm{L}$, respectively; which were lower than that in $\mathrm{Na}_{2} \mathrm{SO}_{4}$ solution.

CGDE was also conducted in mixed electrolyte solution. The concentrations of $\mathrm{H}_{2} \mathrm{O}_{2}$ in $\mathrm{Na}_{2} \mathrm{SO}_{4}$ solutions containing small amount of $\mathrm{Na}_{2} \mathrm{CO}_{3}, \mathrm{NaHCO}_{3}, \mathrm{Na}_{2} \mathrm{HPO}_{4}, \mathrm{CuSO}_{4}, \mathrm{H}_{2} \mathrm{SO}_{4}, \mathrm{NaOH}, \mathrm{NaAc}$ and $\mathrm{NaCl}$ were $62.56 \mathrm{mg} / \mathrm{L}, 59.60 \mathrm{mg} / \mathrm{L}, 63.26 \mathrm{mg} / \mathrm{L}, 64.01 \mathrm{mg} / \mathrm{L}, 63.85 \mathrm{mg} / \mathrm{L}$, $64.02 \mathrm{mg} / \mathrm{L}, 64.66 \mathrm{mg} / \mathrm{L}$ and $56.58 \mathrm{mg} / \mathrm{L}$, respectively. That is, the presence of a small quantity of other electrolyte in solution had slight influence on the concentration of $\mathrm{H}_{2} \mathrm{O}_{2}$.

When a little amount of methanol was in the present of $\mathrm{Na}_{2} \mathrm{SO}_{4}$ solution, the concentration of $\mathrm{H}_{2} \mathrm{O}_{2}$ was $46.71 \mathrm{mg} / \mathrm{L}$, which was also lower than that without methanol. It was because $\mathrm{CH}_{3} \mathrm{OH}$ could capture ${ }^{\bullet} \mathrm{OH}$ due to the following reaction [21]:

$\cdot \mathrm{OH}+\mathrm{CH}_{3} \mathrm{OH} \rightarrow \mathrm{H}_{2} \mathrm{O}+{ }^{\bullet} \mathrm{CH}_{2} \mathrm{OH} \quad k_{11}=8.4 \times 10^{8} \mathrm{M}^{-1} \mathrm{~s}^{-1}$

In practice, methanol was often chosen as the typical hydroxyl radical scavenger.

\section{Conclusions}

In CGDE, $V_{D}$ decreased with the increasing conductivity of solution, and then maintained a certain value. When the con- ductivity was $5.00 \mathrm{mS} / \mathrm{cm}, V_{\mathrm{D}}$ was unaffected by the electrolyte's composition. The different dimension and material of cathode had insignificant effect on $V_{D}$. And the concentrations of $\mathrm{H}_{2} \mathrm{O}_{2}$ in the anolyte were approximately close in $\mathrm{Na}_{2} \mathrm{SO}_{4}$ and $\mathrm{Na}_{2} \mathrm{HPO}_{4}$ solution. The concentrations of $\mathrm{H}_{2} \mathrm{O}_{2}$ in $\mathrm{NaCl}, \mathrm{NaAc}, \mathrm{Na}_{2} \mathrm{CO}_{3}$ and $\mathrm{NaHCO}_{3}$ solution were lower than that in $\mathrm{Na}_{2} \mathrm{SO}_{4}$ solution. The presence of a small quantity of these electrolytes in $\mathrm{Na}_{2} \mathrm{SO}_{4}$ solution had slight influence on the concentration of $\mathrm{H}_{2} \mathrm{O}_{2}$. The presence of $\mathrm{CH}_{3} \mathrm{OH}$ in $\mathrm{Na}_{2} \mathrm{SO}_{4}$ solution decreased the concentration of $\mathrm{H}_{2} \mathrm{O}_{2}$ in the anolyte.

\section{Acknowledgements}

This work was supported by the National Natural Science Foundations of China (No. 20807030 and No. 20837003). The authors would like to thank the Open Foundation of the State Key Laboratory of Environmental Chemistry and Ecotoxicology, Research Center for Eco-Environmental Sciences, Chinese Academy of Sciences (KF2008-10).

\section{References}

[1] R. Wüthrich, P. Mandin, Electrochim. Acta 54 (2009) 4031.

[2] T. Mizuno, T. Akimoto, K. Azuni, T. Ohmori, Y. Aoki, A. Takahashi, Jpn. J. Appl. Phys. 44 (1A) (2005) 396.

[3] R. Wüthrich, V. Fascio, H. Bleuler, Electrochim. Acta 49 (2004) 4005.

[4] R. Wüthrich, C.H. Comninellis, H. Bleuler, Electrochim. Acta 50 (2005) 5242.

[5] H. Vogt, Electrochim. Acta 42 (17) (1997) 2695.

[6] H. Vogt, J. Appl. Electrochem. 29 (1999) 137.

[7] S.K. Sengupta, O.P. Singh, J. Electroanal. Chem. 301 (1991) 189.

[8] S.K. Sengupta, O.P. Singh, J. Electroanal. Chem. 369 (1994) 113.

[9] S.K. Sengupta, A.K. Srivastava, R. Singh, J. Electroanal. Chem. 427 (1997) 23.

[10] H.H. Kellogg, J. Electrochem. Soc. 97 (4) (1950) 133.

[11] A. Hickling, M.D. Ingram, Trans. Faraday Soc. 60 (1964) 783.

[12] H. Vogt, J. Appl. Electrochem. 13 (1983) 87.

[13] S.K. Sengupta, R. Singh, A.K. Srivastava, J. Electrochem. Soc. 145 (1998) 2209.

[14] X.-L. Jin, X.-Y. Wang, H.-M. Zhang, Q. Xia, D.-B. Wei, J.-J. Yue, Plasma Chem. Plasma Process. 30 (2010) 429.

[15] M. Tezuka, M. Iwasaki, Denki Kagaku(Electrochemistry (presently)) 65 (12) (1997) 1057.

[16] M. Tezuka, M. Iwasaki, Thin Solid Films 316 (1998) 123.

[17] L. Wang, J. Hazard. Mater. 171 (1-3) (2009) 577.

[18] J.-Z. Gao, Z.-A. Hu, X.-Y. Wang, J.-G. Hou, X.-Q. Lu, J.-W. Kang, Thin Solid Films 390 (2001) 154.

[19] J.-Z. Gao, X.-Y. Wang, Z.-A. Hu, H.-L. Deng, J.-G. Hou, X.-Q. Lu, J.-W. Kang, Water Res. 37 (2003) 267.

[20] J.M. Aubry, J. Am. Chem. Soc. 107 (1985) 5844.

[21] G.V. Buxton, C.L. Greenstock, W.P. Helman, A.B. Ross, Phys. Chem. Ref. Data 17 (1988) 513. 